\title{
ETHICS IN SYSTEMS ENGINEERING
}

\author{
Joe Kasser \\ The Anticipatory Testing Corporation \\ POB 3419 \\ Silver Spring, MD 20918 \\ Telephone 3015933316 \\ FAX 3015932624
}

\begin{abstract}
Systems are growing larger and larger and are taking over the running of many facets of modern society, such as Automated Traffic Handling Systems, Intelligent Vehicle Highway Systems, and Air Traffic Control Systems. A failure in one of these systems can cause economic damage, as well as loss of life. An engineer who discovers such a problem or even the probability of such a problem faces an ethical dilemma concerning what to about the discovery. This paper discusses personal and corporate ethics in systems engineering; the ethical dilemma faced by a systems engineer and the possible consequences of abiding by one's principles.
\end{abstract}

\section{PERSONAL ETHICS}

Personal ethics deals with the way you relate to the organization and to the people you work with. There are two golden rules within an organization (Kasser 1995) which prescribe the way people behave, namely:

(1) They who have the gold make the rules. Deals with satisfying the customer. Your internal principles (Covey 1989) must not be violated by any process you have to endure to satisfy the customer during the course of your career in an organization. The customer may be external, or internal (upper management).

(2) Treat others the way you'd like to be treated. Deals with interpersonal relationships within the organization. Effective systems engineering is based on team work. You may be the world's finest engineer, but if you can't work on a team, the organization will have little use for you.

\section{CORPORATE ETHICS}

The goal of a corporation is to make a profit within the operational framework of its environment, the law, suppliers, customers, and its employees. However, there are often:

- Tendencies to take short cuts to maximize profit;

- Personal biases; 
The Fifth Annual International Symposium of the National Council On Systems Engineering, St. Louis, MO., 1995

- Plain ignorance;

which may lead to law breaking. The company tries to minimize these tendencies by setting up an "Ethics Program". The purpose of a corporate ethics program seems to be to protect the company from getting caught breaking the law. The best way to avoid getting caught breaking the law is not to break it in the first place. The corporate ethics program is designed to comply with the law.

\section{PROFESSIONAL ETHICS}

Deciding what to do in a situation in which you think something is wrong is not any easy choice. In situations in which death or serious bodily harm has occurred, or will occur the decisions tend to be clear. Situations that are less clear pose much more difficult problems, and are probably more numerous.

\section{INEFFECTIVE SYSTEMS ENGINEERING MAY BREAK THE LAW}

Consider this aspect of the systems development life cycle. In many development projects, $50 \%$ of the time is spent in testing. Now the work performed during this testing phase is either reworking inadequate analysis, design and programming, or doing work that was not done in the first place (Brill 1983). For example, the integration process has just shown that one or more units are not working; however, at the project review prior to the start of the integration phase, the customer was told that the units were tested, pronounced as working and were ready for systems integration. If the customer is not told right away that the problems are within the units, then this situation may constitute mismanagement (fraud) instead of poor management, because the customer thinks the units are working and the contractor now knows differently. This is an implicit lie by omission.

The units now have to be fixed, so to what activity is fixing the units charged to? It may be charged to:

Integration. The tendency (human nature) is not to admit that the units were defective. If the activities carried out to fix the units are charged to Integration, then charging irregularities have occurred because the work is not being charged to the Unit. If MILSTD-2167A applies to the contract then there may be a violation of Section 6.3 (Cost/schedule reporting) of the standard.

Unit development. If the activities are charged to unit development, then those cost accounts were probably closed before the integration phase began. If the customer did not authorize reopening them, then unauthorized charges have accrued and the customer may not need to pay them.

The work has to be charged to either unit development or integration. If you are working on a government contract in a similar situation, you know what charge number you are being told to use to fix up defective units. This scenario would be a great way to identify 
The Fifth Annual International Symposium of the National Council On Systems Engineering, St. Louis, MO., 1995

and get rid of the contractor's ineffective managers if the time spent fixing the units can be shown to have been charged to the integration charge number.

\section{PERSONAL INTEGRITY}

Personal Integrity deals with:

- Trust and Reputation. Being believed in and depended upon.

- Internal principles. and the compromising thereof.

For example, in early 1985, Roger Boisjoly, a senior scientist at Morton Thiokol, predicted a Space Shuttle launch explosion based on the effect of the ambient temperature at the launch site on seals within the launch vehicle. He worked within his organization to effect a change, even unsuccessfully trying to prevent the launch of Challenger the night before the mission was to begin. History records that the launch vehicle exploded a minute or so after lift off on January 28, 1986. Once Boisjoly testified before the Rogers Commission and told the whole story as he saw it, he became a whistleblower and suffered retaliation (Hoffman et al. 1990).

\section{THE ETHICAL DILEMMA}

When you discover an activity, or are asked to participate in, an activity that you feel is wrong, or illegal, remember the golden rules. You have several options. Before making the decision, as a minimum, you may want to ask yourself the following questions (Martin 1993a) as far as they are applicable:

- If I know what's going on, can I live with it?

- If it affects the bottom line, will I still do it?

- If it's not expressly forbidden, will I permit it?

- Is it right to make a profit when someone else's survival is at stake?

- How will I feel about myself at the end of the day if I do something that my conscience tells me is unethical?

- Do I condone or ignore unethical behavior in my company as long as I don't do it personally?

- Does the importance of the individual in my organization determine how I will deal with an unethical act he or she commits?

The Issues. Before you take any action, consider the following issues:

- The law;

- Your motives;

- The company's ethics policy;

- The consequences of your actions.

These issues are discussed below. 
The Fifth Annual International Symposium of the National Council On Systems Engineering, St. Louis, MO., 1995

The law. As an employee, you are regarded as an agent of the corporation which employs you. You have a duty to:

- Obey the directions of your employers.

- Act in your employer's interest in all matters relating to your employment.

- Refrain from disclosing confidential information, which, if revealed, might harm your employer.

However, in the corporate environment, the law:

- Does not require you to carry out illegal or immoral commands.

- Does not authorize you to reveal such commands to the public.

- Will not protect you if you do so (although that may be changing).

- Will not protect you when you refuse to break it.

- Will penalize you if you are caught breaking it.

If you are prepared to stick by your principles, and you are working on a government contract, you may have redress under The False Claims Act, 31 U.S.C. [[section]] 3729 et seq. The False Claims Act, in general covers fraud involving any federally funded contract or program with the exception of tax fraud. The law:

- Grew out of the frauds against the Government in the 1860's.

- Assesses damages of up to three times the dollar amount of the fraud (treble damages), and fines of up to $\$ 10,000$ for each false claim submitted to the government.

- Empowers citizens to act on behalf of the Government and sue the wrongdoer. This unique mechanism is known as qui tam. As a result of amendments in 1986, if a False Claims suit is initiated by a private party, that party is eligible to receive between 15 and 30 percent of the total recovery.

- Seems to have been effective. Qui tam actions have returned nearly $\$ 1$ billion to the Federal Government since 1986 (TAF). Defense contractors have aggressively lobbied Congress to weaken the law.

Your motives. Make sure you know why you are doing what you are doing, because your motives may be questioned. You may be doing it:

- For the money. If you are hoping to make your fortune by way of the qui tam provision in the False Claims Act, watch out! If you delay reporting the matter so that the amount of the fraud increases, you may be at risk for knowing and not speaking out in a timely manner.

- For revenge. Others will be able to see through your attempts at revenge.

- Because you feel it is the right thing to do. You may have to prove it.

The company's ethics policy. In effective companies, management has followed Don Martin's advice and has established and communicated a clear set of business ethics for employees to follow and has created an environment that encourages employees to 
The Fifth Annual International Symposium of the National Council On Systems Engineering, St. Louis, MO., 1995

uphold those ethics (Martin 1993b). The true test of the policy however, is what happens when someone tries to invoke it. In the real world, based on prior case studies (Jos et al. 1989), once you report a problem, irrespective of what the Ethics Policy states, there is a high probability that your career in that organization is over.

If ethics are to be taken seriously in an organization, then the organization must:

- Define the actions the organization deems as unacceptable.

- Develop a method for reporting violations.

- Develop a consistent method of enforcement.

- Punish the violators.

- Develop a process to show that justice has been carried out.

- Protect the reporters of violations.

The consequences of your action. Currently, the typical initial response to the issue is to ignore the charges (Ettorre 1994) and focus instead on the person making the charges (you). Anticipate and prepare for retaliation. Retaliation may take several forms including those listed below (Devine et al. 1988):

- Make the dissenters the issue instead of their message. The company will attack your motives, professional competence, credibility or anything else that will serve to cloud the issue. You will also be labelled as a troublemaker.

- Isolate the dissenters. You will be transferred away from the situation, and isolated from any sympathetic colleagues.

- Make you the scapegoat. They will put you in charge of solving the problem and deny you the resources you need to do the job. You will of course fail, and they will then fire you for cause, namely, failure to perform your assignment in a satisfactory manner.

- Eliminate your job. You will receive a lay off notice even if the company is hiring at the time. This will send a message to your colleagues.

\section{THE APPROACH TO SOLVING THE ETHICAL PROBLEM}

Before you do anything irreversible, make use of your systems engineering skills, as discussed below to:

- Analyze the situation.

- Identify appropriate lessons learned.

- Develop alternative decisions.

- Determine the probable outcome of each alternative decision.

- Evaluate the alternatives.

- Decide what to do and how to go about it.

Analyze the situation. The decision you make will depend on the particular situation. For example, the activity may be: 
The Fifth Annual International Symposium of the National Council On Systems Engineering, St. Louis, MO., 1995

- illegal. For example: bribery; fraud, such as lying, charging to the wrong contract cost account number on a government contract or falsification of test results on government contracts; discrimination based on race, religion or sex. You have to know which laws are broken in order to file a complaint with the Government. The complaint must be filed with the agency authorized to enforce the law.

- Wrong. For example poor management is not illegal, yet results in waste which reduces shareholder dividends. Often laws are introduced after someone has reported that something is wrong because the wrongness is considered bad enough to be made illegal. For example, grass roots organizations have accomplished changes in the environmental laws.

At this time, try to determine what you want to achieve. For example, some goals might be:

- Right the wrong.

- Stop the illegal acts.

- Obtain retribution.

Identify appropriate lessons learned. Apply the lessons learned concept. To anticipate what might happen to you, try to find out what happened to people who followed the company's ethics policy in the past and reported violations.

Develop alternatives. Assuming you want to do something about the situation, the alternatives seem to be:

- Keeping your mouth shut or do nothing.

- Taking part as requested.

- Finding another job and walking away.

- Reporting the situation in an anonymous manner.

- Reporting the situation within the department

- Reporting the situation within the organization

- Reporting the situation outside the organization

Determine the probable outcome of each alternative decision. This is risk management. Examine the consequences of each alternative on your own self esteem. You will have to live with yourself afterwards. The factors you have to consider are real and important, and include:

Anonymity. In many instances you can file a report anonymously. If you decide to file anonymously, then make the report as thorough as you can because you will not get the chance to talk with the investigating authority. Note that anonymity may be difficult to preserve for various reasons, so develop a contingency plan for the day you are identified.

Loyalty. There are several loyalties within the organization. Your loyalty in order of priority is probably to the: 
The Fifth Annual International Symposium of the National Council On Systems Engineering, St. Louis, MO., 1995

- Team you are working with;

- Department;

- Department manager;

- Division;

- Corporation.

When you decide to report something, either within or without the organization, your loyalty will be questioned, and you will be treated as a traitor.

Family. If you decide to report the situation, retaliation will affect your family, directly or indirectly. You need to think about how they will react. It is very important that you discuss the matter with them. A supportive family will make up for a lot of external retaliation.

Friends. If you decide to report the situation, you are going to find out who your friends really are. This factor may be the only reward you get out of the whole episode apart from retaining your self respect.

Finances. If you decide to report the situation you will probably have to find another job. Even if you then take the company to court and achieve a settlement, you will still have to live in the mean time. The company will try to delay reaching a settlement as long as they can in the hope that either you will give up or the statute of limitations will kick in and there will then be nothing you can do about it in a legal manner. You must consider how you will pay your mortgage, food bills, children's tuition and all other bills. Since the situation is going to be stressful, you may end up with medical bills as well. And, if you are unemployed, you may not have any medical insurance.

Evaluate the alternatives. Think long and hard. One of the major risks you will face is family breakup as a result of the pressures that will be brought to bear.

Blowing the whistle. After reviewing the issues discussed above, you make the decision that in order to live with yourself, you have to report the situation. Gather the evidence and do it while the activities are in progress, don't wait until afterwards.

Consult with a Specialist. When faced with an issue regarding reliability, you consult with a reliability engineer. When faced with a production problem, you consult a production engineer, so when faced with a legal issue, consult an attorney or an alternate source of help, with the utmost alacrity. There are several organizations which may be able to help you, if you are working on a government contract, two of them are:

- The Government Accountability Project 810 First Street, NE., Washington DC 20002, telephone (202) 408-0034. Request a copy of their publication "Courage without Martyrdom, A Survival Guide for Whistleblowers". 
The Fifth Annual International Symposium of the National Council On Systems Engineering, St. Louis, MO., 1995

- Taxpayers Against Fraud 1250 Connecticut Avenue NW, Suite 401, Washington, DC 20036, telephone (800) 873-2573 or (202) 296-4826. They specifically deal with the qui tam provisions under The False Claims Act.

If you want to locate an attorney, ask around outside the organization and get a reference to an attorney who specializes in these matters. Your local public library should have a copy of the multi-volume Martindale-Hubble legal directory which lists:

- Most if not all law firms in the US.

- A brief biography of their partners and their specialties.

- If you can't locate a lawyer through your personal network, contact the Bar Association referral service in your area. An attorney can:

- Determine if the activity is against the law.

- Alert you to any laws you might break in documenting the activity and in collecting evidence.

- Help protect you from corporate retaliation, or expiry of the statute of limitations, by anticipating the organization's probable responses and advising you accordingly.

Lawyers however, tend to view problems within the legal framework. Deciding to blow the whistle is a question of your own integrity, so while the attorney will advise you, in the end, the decision is yours, and yours alone.

Open a diary. Open a diary and write everything in it. Use a bound book rather than loose pages and a binder. The diary will serve the same purpose as the engineering notebook you use to record action items and notes during technical and staff meetings. Document:

- Who said what to whom.

- Who was present at the time.

- References to documents or other evidence you have found or have heard about.

If you think you will need to prove you wrote something on a certain date, mail a copy to yourself, but don't open the letter when it arrives. The postmark on the sealed envelope will be proof. If you are really concerned, register the letter.

Gather the evidence. You will need as much evidence about the situation as you can obtain. This may take the form of documentation or prototypes. If you can't obtain all the evidence, then try to find out where it can be obtained. However, do not do anything illegal to obtain the data you need. If the matter does end up in court, evidence obtained in an illegal manner tends to be ruled as inadmissable. Gather what you need before you file the report, you may be cut off from your source material once the report is received.

Follow procedure. Follow the organization's procedure for reporting the activity, i.e. work within the system. If there is an ethics policy, follow it. If not, discuss the matter with a supervisor or manager you feel you can talk to. Note in your diary what you said 
The Fifth Annual International Symposium of the National Council On Systems Engineering, St. Louis, MO., 1995

to whom and when. If you don't feel that you can talk with anyone in your division, locate someone at corporate headquarters. Report the activity in writing as well as verbally and stick to the facts. Write your report in the same way as you'd write any technical report.

Enclose copies of technical data and supporting information as appendices in your report. Keep a copy of every item included. Make sure there are plenty of copies of your report with fellow employees or friends you trust. Don't seek publicity, but at the same time, don't acquiesce to the corporate request to keep the matter confidential. Confidentially works in their favor not yours. If someone within the company asks you about the matter, be truthful. Don't sabotage yourself.

Keep emotions out of the picture and never, ever, threaten anyone. Politely request answers by specific dates. If you do not get a timely answer, work your way up the chain of command, but only advance if you seem to be encountering delays. Remember the law has statute of limitations.

Use your diary to document what happens to you after you make your initial complaint, your situation may end up in court. However, going to court is usually a lose-lose situation. If you can't resolve the matter within the organization, you will have to go outside the organization. Where to go depends on the activity.

External Options. If you are working on a Government contract, signs must be posted to tell you where to report violations of the law. Let your conscience be your guide after careful and deliberate thought. If you do file a complaint with a Government agency, there will be an initial dialogue. In the case of the Equal Employment Opportunity Commission, the Intake Officer will tell you what to expect, describe the process, and give you an optimistic estimate of the time you can expect the process to take. After the initial dialogue, six months or more may pass before you hear anything. If you telephone an agency hot line, you will be contacted by someone from the agency Inspector General's office and once again, the procedure will be lengthy.

\section{SUMMARY}

Sticking by your principles and reporting wrongdoing is a tough road to take. In these situations, history teaches us that the good guys usually suffer for taking a stand. Yet, knowing that, good guys still take a stand. Courage is doing what you feel you have to do when you don't want to do it.

\section{REFERENCES}

Boisjoly, Russell P., Curtis, Ellen Foster, "Roger Boisjoly and the Challenger Disaster: A Case Study in Management Practice, Corporate Loyalty and Business Ethics", as printed in, Hoffman, W. Michael, Moore, Jennifer Mills, Business Ethics, Second Edition, McGraw-Hill Publishing Company, 1990. 
The Fifth Annual International Symposium of the National Council On Systems Engineering, St. Louis, MO., 1995

Brill Alan E., Building Controls into Structured Systems, Yourdon Press, 1983, p 130.

Covey, Steven R., The 7 Habits of Highly Effective People, Simon \& Schuster, 1989.

Devine, Thomas M., Aplin, Donald G., "Whistleblower Protection-The Gap Between the Law and Reality", Howard Law Journal, Vol 31, 1988.

Ettorre Barbara, "WHISTLEBLOWERS: Who's the Real Bad Guy?", Management Review, May 1994, pp 18-23.

Jos, Philip H, Tompkins, Mark E., Hays, Steven W., "In Praise of Difficult People: A Portrait of the Committed Whistleblower", Public Administration Review, November/December 1989.

Kasser, Joe., Applying Total Quality Management to Systems Engineering, Artech House, 1995.

Martin Don, Teamthink: Using the Sports Connection to Develop, Motivate and Manage a Winning Business Team, Dutton, 1993, p 208.

Martin Don, Teamthink: Using the Sports Connection to Develop, Motivate and Manage a Winning Business Team, Dutton, 1993, p 201.

Taxpayers Against Fraud, The False Claims Act, Legal Center, information sheet.

\section{BIOGRAPHY}

Joe Kasser is president of the Anticipatory Testing Corporation, an organization he founded to reduce cost and schedule overruns in systems engineering. He has spent the last 20 years applying TQM to Systems Engineering resulting in the achievement of the cost effective implementation of international and domestic aerospace, communications and solar power systems. He is a recipient of NASA's Manned Space Flight Awareness (Silver Snoopy) Award for quality and technical excellence. He is also an Institute of Certified Professional Manager's (ICPM) Certified Manager (CM) and a recipient of the ICPM's 1993 Distinguished Service Award. Parts of this paper were developed for his proposed doctoral dissertation at The George Washington University as well as his book on "Applying Total Quality Management to Systems Engineering". Material from the book is reproduced with permission from Artech House. 